\title{
CHRISTUS AGELASTUS: O RISO E O PENSAMENTO CRISTÃO NA IDADE MÉDIA.
}

José Rivair Macedo"

SÍNTESE - A questão do riso, do sorriso e da gargalhada foi recebida no cristianismo de forma diferente do que o fora nas sociedades arcaicas e nos cultos greco-romanos. Se em inúmeros rituais pagãos o riso fazia parte da liturgia, não acontece o mesmo na seriedade do culto cristão, chegando-se mesmo a afirmar que Cristo jamais sorriu. Com a revalonização das categorias profanas da existência, a partir do século XII, também o riso e os demais sinais exteriores de expressão são revalorizados.
ABSTRACT - Laughter, smile and burst of laughter didn't have the same value among Christians as they had in the ancient societies as well as in the religious cults of Greece and Rome. In numberless pagan rituals the laughter was integrated into the liturgy, but it wasn't allowed in the Christian cult, because Christ, as it was usual to say, never had laughed. With the revaluation of the profane categories of the existence, the laughter and the other external signs of expression were also revalued.

No mundo antigo, o riso desempenhava variados papéis, inclusive de cunho religioso. No início deste século, Salomon Reinach demonstrou o modo pelo qual ele esteve associado a um complexo de mitos ou ritos, sobretudo aqueles praticados em homenagem às deusas da vegetação ou entes ligados à fertilidade. Quando tomado em sua forma ritual, o gesto esteve integrado aos cultos agránios. As mascaradas, libações e procissões licenciosas perpassadas pelo riso pertenceriam, nesse sentido, ao âmbito do sagrado, e o gesto indicaria, nesse sentido, certa forma de ligação entre os homens e os deuses.'

Vladimir Propp, outro importante estudioso do problema, sustenta que, nas sociedades antigas, a agricultura criou deuses e deusas, tanto quanto a idéia de que, para fazer crescer a erva e o trigo, era preciso fazer rir a deusa Terra e/ou dar-lhe um marido. Os indícios da referida crença podem ser encontrados nas

- Este trabalho integra-se ao projeto de pesquisa "O riso e o cômico na cultura medieval", desenvolvido entre 1995-1997, sendo agraciado com bolsa de produtividade em pesquisa pelo CNPq.

- Universidade Federal do Rio Grande do Sul - UFRGS.

1 Salomon REINACH. "Le rire rituel". In: Cultes, mythes et religions. Paris: Emest Leroux, 1906.

Tome IV, pp. 109-129.

\begin{tabular}{|l|l|l|l|l|l|}
\hline VERITAS & Porto Alegre & v. 42 & $\mathrm{n}^{2} 3$ & Setembro 1997 & p. 549-567 \\
\hline
\end{tabular}


tradições míticas concernentes à hierogamia entre Zeus e Hera na festa de Daedala. Outros elementos constitutivos da identificação profunda entre riso e ritual aparecem na celebração dos Mistérios de Eleusis, em honra de Deméter; nos cultos dionisíacos gregos, nas Saturnais e Lupercais romanas, bem como nas cerimônias em homenagem a Isis, do Egito. Em todos os casos citados, malgrado as especificidades e particularidades, podemos observar elementos do caráter hierofânico da risibilidade, e a reafirmação da crença de que o gesto seria imbuído de propriedades terapêuticas, sendo capaz de proporcionar fertilidade aos campos e aos homens. ${ }^{2}$

O riso ritual, perfeitamente integrado nas formas religiosas do Ocidente, não perdeu este traço durante a antiguidade Tardia e a Idade Média, mantendo-se vinculado ao complexo de manifestações perpassadas pelo espirito festivo carnavalesco, que Mikhail Bakhtin denominou cultura cômica popular. ${ }^{3}$ Neste estudo, todavia, pretendemos verificar qual o lugar ocupado pelo gesto nos códigos culturais pertencentes aos sistemas de valores do pensamento cristão. Como o riso, gesto amplamente prestigiado nas formas de sociabilidade popular, tomado como símbolo da vida, veio a ser tratado pelo Cristianismo, uma religião da morte?

Entendamos bem, morte do corpo, na expectativa da realização plena do espírito. Enfatizando as glórias da vida eterna, a ética cristã incentivou a renúncia aos prazeres terrenos e inclusive a renúncia ao próprio corpo, valorizando a continência e o rigor moral como condições para a purificação da alma na preparação para o reencontro com Deus. Lembremos da passagem da Epístola aos Colossenses, em que o apóstolo Paulo diz: "Afeiçoai-vos às coisas que são lá de cima, não às que estão sobre a terra. Porque estais mortos e a vossa vida está escondida com Cristo em Deus". ' Como apontaremos a seguir, esta orientação básica da doutrina cristã esteve no âmago de toda a argumentação teológica e moral desenvolvida em torno do significado do riso na Idade Média.

A afirmação do Cristianismo no contexto de crise do mundo romano e de formação da Idade Média representou, em todos os sentidos, um ponto de ruptura com as formas de sociabilidade e sensibilidade da Antigüidade. A ética e a moral cristãs ofereceram perspectivas bastante distintas daquelas vigentes no mundo antigo - vistas pelos adeptos da nova religião como manifestações pagãs e, em geral, condenáveis por distanciarem o homem da verdade suprema da salvação -, propondo ideais e/ou valores novos na relação do homem com o sagrado, capazes de, no decurso dos séculos, imprimir códigos de conduta bastante originais. ${ }^{\circ}$

Com Peter Brown, reconhecemos na obra doutrinal dos integrantes da Patrística um esforço no sentido de conferir universalidade às premissas cristãs, pela

2 Vladimir PROPP. "O riso ritual no folclore". In: Édipo à luz do folclore (Quatro estudos de etnografia histórico-cultural). Lisboa: Editorial Vega, s/d, p. 89.

3 Mikhail BAKHTIN. A cultura popular na Idade Média e no Renascimento: o contexto de François Rabelais. SP: HUCITEC, 1987.

1 Epistola aos Colossenses, 3, 2. As citaçōes foram retiradas da tradução da Vulgata pelo Pe. Matos SOARES. SP: Edições Paulinas, 1979.

- Para o debate a respeito da dessacralização das formas religiosas antigas dentro do pensamento cristão, ver Claude GREFFÉ. "Le christianisme et les métamorphoses du sacré". In: VVAA. II Sacro: studi e ricerche. Roma: Centro Internazionali di Studi Umanistici, 1974, pp. 134-150. 
prédica ou pela especulação, arraigando-as entre os poderosos e os humildes, transformando-as em artigos de fé e condiç̧ão obrigatória para a salvação. Ao contrário das crenças antigas, ritualizadas e concretizadas em fórmulas exteriores, o cristianismo ofereceu uma via de acesso ao sagrado pela interioridade e introspecção, penetrando na intimidade, procurando atingir o coração e a alma dos crentes, num constante exercício de disciplina, numa atitude perpassada pelo sentimento de temor a Deus. ${ }^{6}$

O cristianismo, sobretudo a partir da elaboração de seus primeiros adeptos, veio a ser erigido em torno de principios morais elaborados a partir de uma perspectiva transcendente. Nesta perspectiva, o lugar ocupado pelo corpo e pela sexualidade deslocou-se do plano positivo em que se encontrava - especialmente pela significação que tinham nos rituais religiosos politeístas - para o âmbito negativo do pecado. 0 cristianismo primitivo, impregnado pelas idéias neoplatônicas e estóicas, negou o existencial em favor do espiritual, do transcendental, estabelecendo uma dicotomia entre existência e espírito, mundo carnal e mundo espiritual, profano e divino, pecado e salvação, idealizando o celibato e a virgindade, a austeridade e a abstinência."

O modo pelo qual os escritores cristãos retrataram os elementos míticos da tradição pagã concernentes aos rituais de fertilidade, pode nos fornecer clara noção do grau de alteração no modo de perceber a dimensão sagrada da derrisão. Diversas versões de mitos greco-romanos vieram a ser inscritos nos textos da literatura latina cristã. Eusébio de Cesaréia, Arnóbio e Clemente de Alexandria, por exemplo, registraram o mito de Deméter e Baubo, mas encontraram nele sentido distinto daquele verificado na cultura grega, enfatizando apenas o aspecto nefasto do riso, que passa a ser tomado na qualidade de gesto puramente obsceno." De modo similar, foi para denunciar a indecência das faloforias, dos cultos a Baco e a Dioniso, que os Pais da Igreja vieram a inscrevê-los em seus textos. O riso, portanto, passou a estar indelevelmente associado à falta de pudor, aos cultos idolátricos e ao pecado, o que contribuiu bastante para a desconfiança dos teólogos cristãos em relação a ele."

Nestes novos comportamentos mediadores entre o homem e o Deus cristão, a busca da interiorização far-se-ía pelo controle da palavra e dos gestos, pela educação do corpo, negação dos apetites carnais, contenção dos impulsos desordenados, enfim, pelo autocontrole físico e espiritual. A conquista da interioridade implicou na valorização da pobreza, castidade e obediência, e se fez pelo exercício da

- Peter BROWN. Genèse de l'Antiquité Tardive. Trad. Aline Rousselle. Paris: Gallimard, 1983 e "Antiguidade Tardia". In: ARIÉS/DUBY (Dir). História da vida privada. Trad. Hildegard Feist. SP: Companhia das Letras, 1991. Tomo I - Do Império Romano ao Ano Mil, pp. 243-299.

7 Nesse sentido, ver Philippe ARİ̀S. "São Paulo e a carne", pp. 50-53 e Michel FOUCAULT. "O combate da castidade", pp. 25-38. In: Philippe ARIËS/André BEJIN (Orgs). Sexualidades ocidentais. Trad. Lygia A. Watanabe e Thereza C. F. Stummer. SP: Brasiliense, 1986.

- Maurice OLENDER. "Aspects de Baubo". Revue de l'Histoire des Religions, CCII-1, 1985, p. 13, 1619.

- Para a dessacralização dos mitos antigos e sua interpretação segundo as premissas cristãs, cf. Jean-Claude SCHMITT. "Problemas do mito no Ocidente Medieval". Trad. Denise Maria Cogo. In: Donald SCHÜLER/Miriam B. GOETTEMS (Orgs.). Mito: ontem e hoje. Porto Alegre: EDURGS, 1990, pp. $45-46$. 
prece, realizada na solidão e no silêncio: A convicção íntima tendeu a tornar-se o motor das ações pessoais. Ao mesmo tempo, a vigília de si mesmo conduziu a um auto-policiamento e a um combate constante contra as forças desagregadoras do espírito. ${ }^{10}$

O riso passou a ser considerado uma destas forças. Os polemistas cristãos, em virtude da natureza da crença que professavam, não reconheceram qualquer grau de sacralidade, nem reconheceram qualquer vinculação do riso com a divindade, tal qual ocorria na tradição pagã que tanto procuraram combater. Nos sistemas de valor do cristianismo, este foi dessacralizado e reduzido à categoria de gesto profano. Como podia ser diferente? Na condição de gesto, todavia, o mesmo seria revestido de conotações negativas. Negá-lo eqüivalia a abrir caminho para o encontro consigo próprio e com Deus. Signo do caos e da desordem, o riso cederia passo, na escala de valores defendida pelo cristianismo, à sobriedade e continência moral.

O fundamento da negação cristã ao riso pode ser encontrado em germe na tradição judaica. Nos textos vetero-testamentários, é possível perceber certa ambivalência quanto ao lugar a ser ocupado pela risibilidade. Condenando-a e restringindo-a, o pensamento judaico permitiu-lhe apenas um minúsculo espaço de manifestação."

Há, pode-se dizer, elementos cômicos no Antigo Testamento. Que dizer do episódio da luta entre Hebreus e Filisteus, em que Sansão juntou trezentas raposas, amarrando-as umas às outras pelas caudas com fachos no meio, acendendoos e largando-as, para que os animais destruíssem as vinhas e os olivais do inimigo? Ou, quando o mesmo Sansão, com uma queixada de jumento, deu cabo de mil filisteus $?^{12}$ Ou ainda a desventura do rei Saul quando, por ocasião da perseguição a Davi, entrando numa caverna para satisfazer suas necessidades fisiológicas, expôs-se ao olhar do adversário, que ali encontrava-se refugiado? ${ }^{13}$

Em raríssimas passagens, o escárnio e a zombaria são emprestados a Javé como instrumento de correção dos descrentes ou inimigos do povo de Israel. Neste sentido, lemos nos Salmos: "Aquele que habita no céu zombará deles, e o Senhor os escarnecerá"; "Tu, Senhor, zombarás deles, reduzirá a nada todas as gentes". "Nada nessas passagens permite perceber o riso como forma de expressão da alegria. O riso de Javé é mordaz e destruidor, signo distintivo de seu inextinguivel poder. De um modo geral, o Antigo Testamento forneceu ao cristianismo repertónio significativo de restrições em relação à derrisão. A tradição hebraica associa 0 ato risivel a dois vocábulos: Çahaq designa um riso que exprime a alegria e a satisfação, enquanto Lahaq designa o riso zombeteiro de déboche e escámio, revestido de conotações negativas. ${ }^{15}$ Particularmente nos textos sapienciais, esta segunda modalidade passa a ser condenada. No Livro dos Provérbios, a zom-

10 Michel ROUCHE. "Alta Idade Média ocidental". In: ARIĖS/DUBY (Dir). História da vida privada. Tomo I, pp. 437-462.

11

Cf. René VOELTZEL. Le rire du Seigneur. Strasbourg: Éditions Oberlin, 1955, esp. pp. 29-53.

Juizes, 15, 4-5, 16.

I, Samuel, 24, 4-6.

Salmos, 2, 4; 58, 9.

René VOELTZEL. Le nire du Seigneur, p. 55. 
baria é aproximada da insensatez, tolice, orgulho e vaidade, ${ }^{10}$ e no Eclesiástico lemos: "O insensato, quando se ri, levanta a sua voz/ mas o varão sábio apenas se sorrirá em silêncio"."

Tal tendência viria a ganhar contornos mais definidos na tradição cristã inaugurada no Novo Testamento. Neste caso, a condenação aparece com maior veemência, e o riso chega a ser colocado na condição de obstáculo capaz de distanciar o fiel de Deus: "Rejeita as fábulas ridiculas e os contos de velhas, e exercita-te na piedade"." Desde os primórdios da religião, os elaboradores da doutrina enfatizaram o sofrimento como meio de purificação, em oposição à condição efêmera do prazer e da alegria terrena: "Alegrardes de serdes participantes dos sofrimentos de Cristo, para que vos alegreis também e exulteis, quando se manifestar a sua glória". ${ }^{9}$ Fruto do mundo (baixo, vil), o riso seria desaconselhado: "Está triste algum de vós? Faça oração. Está alegre? Cante Salmos"; agora rides! Porque gemereis e chorareis". ${ }^{21}$

Reduzido à categoria de gesto representativo das atitudes consideradas reprováveis, o riso acabou sendo integrado no campo de reflexão dos pensadores da Patrística quando estes escreviam a respeito do modo de conduta dos fiéis. Os papéis atribuidos aos gestos, bem como o significado explícito ou implícito de cada um deles, constituiu objeto de preocupação dos moralistas e pensadores no decurso de toda a Idade Média. Num mundo cuja comunicação far-se-ía basicamente por via oral, e que o domínio da escrita seria o apanágio de uma minoria de letrados, a compreensão dos códigos de comunicação focalizados na gestualidade e nas palavras, permaneceria um dado fundamental. Para os pensadores que os examinaram, no corpo figurariam os secretos movimentos do espírito, escondidos no interior de cada pessoa. Os gestos, costumava-se dizer, eram o "espelho da alma".

Como controlar os gestos considerados excessivos, discipliná-los, suprimi-los, ou, por outro lado, conferir-lhes novo sentido, condizente com o espirito cristão? No século III, esta indagação norteou o pensamento de Clemente de Alexandria, entre os primeiros escritores cristãos a apropriar-se de elementos da ética pagã, convertendo-os em favor dos ideais da nova doutrina. No longo tratado intitulado Paedagogus, Cristo é invocado como o grande educador, cujos conselhos e orientaçōes deveriam guiar a todos os fiéis. Fundamentando-se nas Escrituras, mas também em Platão, Aristóteles ou Sêneca, Clemente elaborou uma série de preceitos educativos, relacionados tanto com a conduta espiritual quanto com os atos corriqueiros do dia a dia, destinados a formar o homem segundo o modelo cristão. ${ }^{73}$

16. A sensação de precariedade do riso e da alegria no Livro dos Provérbios advém da perspectiva dos redatores dos textos sapienciais, talvez em razão do próprio contexto em que tais textos vieram a ser escritos. L. Alonso SCHOKEL/J. VLCHEZ. Proverbios. Madrid: Ediciones Cristiandad, 1984, p. 163. Ver ainda A. BARUCQ. Le livre des Proverbes. Paris: Librairie Lecoffre, 1964.

Eclesiástico, 21, 23.

I, Timóteo, 4, 7.

I, Pedro, 4, 13.

Tiago, 5,13 .

Lucas, 6, 25.

Jean-Claude SCHMITT. La raison des gestes dans l'Occident médieval. Paris: Gallimard, s/d.

Alois DEMPF. Etica de la Edad Media. Trad. Jose Pérez Riesco. Madrid: Ed. Gredos, 1958, p. 54. 
Na parte do Paedagogus dedicada aos comportamentos desejáveis do bom fiel, Clemente aborda a questão do riso. Para ele, os amantes da derrisão deveriam ser excluídos da comunidade cristã. A bufonaria e as palavras ridículas deveriam ser desprezadas. As palavras, sendo o fruto do pensamento, revelariam a essência do homem. Neste raciocínio, as palavras baixas, cômicas e risíveis, rebaixariam quem as pronunciasse e quem as escutasse. Reparemos, pois, na argúcia com a qual o moralista aborda o problema. Para evitar o gesto, seria preciso cortar pela raiz os seus estímulos. Associando as palavras bufas, e o subsequente riso bufo, ao baixo, Clemente vincula-os à baixeza da terra, distanciando-os do ideal elevado e celeste das virtudes cristãs valorizadas.

Segundo Clemente de Alexandria, conquanto o riso não pudesse ser suprimido do comportamento dos homens, era preciso pelo menos discipliná-lo. Dentro de certos limites, ele poderia revelar o equilíbrio da alma. Em caso contrário, tornarse-ía perigoso e indicaria o desregramento espiritual. Reproduzindo parecer similar ao da literatura sapiencial hebraica, para ele o sorriso comedido apontaria o sábio, enquanto a expressão desmesurada deveria ser tomada como Kichlismos, o riso das prostitutas, ou Kanchasmos, o riso dos proxenetas. Não seria aconselhável rir a todo o momento, nem demoradamente. Era preciso distinguir os momentos e as circunstâncias em que o mesmo poderia se manifestar sem ofender a Deus, sendo aconselhável evitar rir na presença dos mais velhos, de pessoas a quem se devia respeito, ou de estranhos."

A posição de Clemente oscilou entre a negação e a incorporação do gesto ao ideário cristão. Neste ponto, ele pode ser situado entre a vertente moderada do pensamento cristão, preocupada em conciliar os modelos de conduta defendidos com as formas de sociabilidade aceitas e difundidas entre a elite do mundo romano. Em seguida, todavia, a moderação acabou sendo substituida por posições bem mais extremadas, cujo principal representante veio a ser, no início do século $\mathrm{V}$, o severo Bispo de Constantinopla, São João Crisóstomo. Tendo vivido numa época em que os valores do mundo clássico periclitavam diante da profunda crise social, econômica, política, espiritual e moral vivenciada nos momentos finais de agonia do Império Romano, este moralista mostrou-se bastante reticente em relação aos costumes dos seus contemporâneos, pregando com entusiasmo a necessidade da contrição e da renúncia aos deleites aparentes da vida mundana.

Foi São João Crisóstomo o responsável pela formulação dos argumentos clássicos que viriam a ser reiteradamente utilizados por moralistas e escritores posteriores, visando banir o riso da esfera oficial da doutrina cristã. Em seus textos, os autores pagãos não mais aparecem mencionados. Os fundamentos da profunda repulsa em relação ao riso passaram a ser buscados diretamente nos textos sagrados do Novo Testamento. A condenação reveste-se de grande truculência. Para Crisóstomo, era preciso varrer o riso do comportamento dos leigos e dos integrantes da Igreja. Em uma de suas célebres homilias, dedicada à interpretação do texto pauliniano da Epístola aos Hebreus, o gesto aparece caracterizando condutas desaprovadas: "O riso degrada e arruina tudo; ele subsiste em nossos hábitos e

* CLĖMENT DE ALEXANDRIE. Le pedagogue. Éd. et Trad. Marguerite Harl (Sources chrétiennes, 70). Paris: Du Cerf, 1960. Livre II, cap. V, pp. 99-105. 
costumes, em nossos prazeres e em nossas relações". A partir da constatação, e seguindo as premissas de São Paulo, sugere a única via de purificação:

"Choremos, meus caros irmãos, choremos para que possamos rir e nos divertir sinceramente ao tempo da verdadeira alegria. As alegrias daqui de baixo são inteiramente misturadas de tristeza. Nunca são puras. As do alto, distantes de toda malícia, de toda impostura, são desprovidas de qualquer perigo" ".

São João Crisóstomo, com toda razão, ganhou o epiteto de "João Boca de Ouro". Dotado de singular capacidade discursiva e de grande eloqüência, pode ser considerado um dos maiores retóricos do periodo de formação da Igreja. Dois de seus argumentos exerceram bastante influência sobre as impressões dos pensadores cristãos do medievo a respeito do riso: em primeiro lugar, segundo ele, o riso possuiria essência demoníaca; e em segundo, Cristo nunca teria rido. De fato, em seus escritos, a idéia do riso aparece constantemente associada às esferas da danação. O gesto é identificado ao furor, à possessão, à demência e à blasfêmia, defeitos e vícios capazes de tornar o coração impenetrável às verdades eternas. Como rir, argumentava, sabendo que o dia do Juizo se aproxima? E concluia: "Não é Deus que nos inspira este gosto pelo divertimento, é satã". ."

No caminho reto para o reencontro com Cristo, melhor seria imitá-lo. E Cristo, segundo Crisóstomo, manteve-se sempre como agelasto, sem jamais ter rido. Pelo contrário, argumentava o pensador, o Evangelho mostra-o em constante tristeza. E, apoiando-se uma vez mais em São Paulo, afirmava ter Cristo chorado de noite e de dia, por três anos. Como então, perguntava, consumir-se no riso vão? E arrematava: os que rissem muito não seriam dignos de perdão, enquanto os que servissem a Deus com lágrimas seriam lavados do pecado e isentos de punição."

Os pensadores da Igreja latina, mesmo não tendo sido completamente favoráveis ao riso, jamais impingiram-lhe tais admoestações. Santo Agostinho, em $D e$ Catechizandis Rudibus, tratado destinado à orientação doutrinal para a catequese dos neófitos cristãos, chega mesmo a dar instruções aos missionários, no sentido de que integrassem em seu discurso palavras simples e exemplos agradáveis, de modo a provocar o bom humor e ganhar a simpatia dos ouvintes. A transmissão da mensagem em linguagem clara e bem humorada evitaria a aversão, o cansaço ou os bocejos do auditório, infundindo paz na alma e despertando o interesse das "ovelhas" a serem arrebanhadas. ${ }^{\text {" }}$

Agostinho, todavia, não deve ser tomado como defensor da derrisão. No caso apontado, o riso deveria ser empregado como estratégia na consecução de uma missão muito mais importante: difundir a mensagem de Deus. ${ }^{2}$ Em sua autobio-

* SAINT JEAN CHRYSOSTOME. Homélies sur l'Epitre aux Hébreux. In: Oeuvres completes. Trad. J. Bareille. Paris: Louis Vivès, 1873. Tome XX, p. 284.

ns SAINT JEAN CHRYSOSTOME. Homélies sur Saint Mathieu. In: Oeuvres Completes. Tome XI, p. 362.

\#Idem, p. 361.

* SAINT AUGUSTIN. De Catechizandis rudibus. In: Oeuvres de Saint Augustin. Éd. G. Gombes e l'Abbé Fargues. Paris: Desclée de Brouwer, 1949. Tome 11, pp. 54-80.

* O referido tratado exemplifica bem as estratégias discursivas e estilisticas do bispo de Hipona, que resultaram na elaboração de princípios retóricos completamente distintos daqueles vigentes na cultura clássica, pois a mensagem devia atingir completamente a compreensão do grande público, tornando-se instrumento para a pregação e as verdades últimas da fé. Nesse sentido, ver Eric AU- 
grafia espiritual, as Confissões, ele rememora com tristeza suas experiências de infância, quando, junto com outros meninos, divertia-se ao enganar os mais velhos para apanhar frutas em árvores alheias. Desta lembrança, extrai uma lição para o homem maduro: é muito mais difícil rir quando se está só. A solidão deveria servir como meio para evitar o riso fácil e pernicioso. Algumas vezes, porém, o impulso podia ser forte a tal ponto de vencer o solitánio, e ele poderia surpreender-se rindo quando voltasse à sua memória - invadindo os pensamentos e dominando os sentidos - algo digno de despertar esta emoção. Seria necessário, pois, vigiar-se a todo o momento, mesmo na intimidade, para salvaguardar a integridade do espírito. ${ }^{30}$

Riso e solidão. As rememorações de Agostinho aproximam-nos de outra vertente do pensamento cristão muito reticente em relação ao gesto aqui enfocado. Referimo-nos à tradição monástica, iniciada pelos místicos e anacoretas do deserto e continuada pelos solitários cenobitas dos mosteiros, que viria a exercer extraordinária influência na formação do ascetismo medieval.

A busca de purificação e perfeição espiritual empreendida por anacoretas, eremitas e cenobitas fundava-se numa promessa de austeridade e ascese excepcionais. O monge é um homem solitário, destinado a encontrar-se com Deus pelo caminh? da renúncia, do sofrimento e da disciplina. A solidão do deserto, experimentada pelos primeiros místicos orientais, transformou-se, no caso dos monges ocidentais, na solidão da comunidade organizada em tomo de um mosteiro. A vida monacal representa um ponto de ruptura decisivo com o espaço profano. Fechado em torno de si mesmo, o mosteiro deveria assemelhar-se ao Paraíso. Em espaço sacralizado, normatizado, governado por princípios rígidos, esses "novos Adões" deveriam limitar-se a ler/escrever, orar, meditar e realizar trabalhos manuais."

Para chegar mais perto de Deus, seria preciso que o espírito se desprendesse de tudo o que estivesse relacionado com 0 mundo. A privação e a abstinência total equivaleriam à morte de si enquanto homem comum, isto é, à morte do corpo. Enquanto os instintos imperassem, a alma permaneceria escravizada ao invólucro carnal. Tratado como adversário perigoso, o corpo deveria ser submetido e controlado. $\mathrm{O}$ instrumento deste combate deveria ser encontrado na regra sob a qual a comunidade passaria a viver. Santo Agostinho redigiu uma destas regras monásticas. Não foi o único. São Basilio antes, e São Colombano depois, dedicaram-se à elaboração de textos similares. ${ }^{2}$

Como mortificar o corpo e purificar o espirito, extirpando todas as possibilidades do riso franco? Em geral, os redatores dos textos destinados a servir de modelo para a vida claustral preocuparam-se com a questão da admissibilidade do

BERCH. Lenguaje literario y publico en la Baja Latinidad y en la Edad Media. Trad. Luiz L. Molina. Barcelona: Ed. Seix Barral, 1969, esp. pp. 46-56, em que discute o surgimento do conceito de sermo humilis.

II SAN AUGUSTIN. Confesiones. Trad. R. P. Fr. Eugenio Ceballos. Buenos Aires: Ed. Poblet, 1941. Libro II, cap. IX, pp. 75-76.

r. Para a evolução da vida monacal no Ocidente, ver Jean DECARREAUX. Les moines et la civilisation en Occident. Paris: Arthaud, 1962.

sobre as implicaçōes culturais e os traços gerais da vida monástica, cf. Valdemar VEDEL. Ideales culturales de la Edad Media. Trad. Jaime Ruiz Manent. Barcelona: Ed. Labor, 1948. Tomo IV- La vida monastica, esp. pp. 126-139. 
riso na conduta dos monges e, de um modo geral, partiram dos mosteiros as restrições mais severas em relação ao referido gesto. Podemos observar já no texto da Instituta Monachorum Sancti Basilii, isto é, a Regra de São Basilio, redigida em 365 nas proximidades de Cesaréia, os primeiros argumentos contrários à derrisão, que viriam nos séculos seguintes a se afirmar dentro do que se convencionou chamar "paradigma monástico".

A Regra de São Basílio foi organizada e desenvolvida na forma de questões com os subsequentes comentários, perfazendo um grande diálogo entre um suposto mestre e um suposto noviço. A questão de número XVII desenvolve as reflexões concernentes a necessidade e o modo de conter o riso. Para o redator, ser dominado pelo riso imoderado e imódico é sinal de intemperança, intranqüilidade e tal atitude denota o relaxamento espiritual. O sorriso sereno, por outro lado, por mostrar a expansão da alma, não é por si mesmo inconveniente. O problema, portanto, estava relacionado ao grau de intensidade das emoções, às quais o monge deveria ser capaz de controlar: "Rir-se alto e sacudir-se involuntariamente não é próprio de quem possui espírito tranqüilo, probo e senhor de si”. Quanto a questão relacionada à permissão concedida ao mesmo, a resposta é clara e objetiva: "Como o Senhor condena os que riem agora, é evidente não haver para o fiel tempo algum próprio ao riso, principalmente sendo tão grande a multidão dos que ofendem a Deus, por violação da lei, e morrem no pecado; por todos eles devemos contristar-nos e gemer". .3 $^{3}$

O modelo claustral adotado no Ocidente, todavia, seria extraído da Regula Sancti Benedicti, a Regra de São Bento, redigida em meados do século VI para ser aplicada no mosteiro de Monte Cassino, em que o célebre asceta veio a ser líder espiritual. No decurso dos séculos, o texto da regra acabou sendo adotado por diversos mosteiros, tornando-se a principal referência sobre os princípios orientadores da disciplina espiritual do clero regular. ${ }^{\text {"n }}$

Qual o lugar do riso neste texto modelar do comportamento monacal? Encontramo-lo em diversos trechos da Regula. No capitulo VI, denominado De Taciturnitate, ou seja, sobre o "silêncio", Bento exorta o leitor a exercitar-se no mais completo isolamento. Como no deserto, no cenobium deve o monge continuar a ser um solitário. A palavra, signo da união pela comunicação, deve ser restringida, pois aqueles que habitam numa comunidade monástica separam-se da relação com os homens. Guardar silêncio com os homens permite que se possa falar interiormente com Deus. A restrição é muito mais categónica quando se trata de palavras capazes de suscitar o riso: "Os gracejos frívolos e as conversas ociosas e provocadoras de riso, condenamo-las a serem excluidas para sempre de todos os lugares e não permitimos ao discípulo abrir a boca para tais conversas":

* SÃO BASLliO MAGNO. As regras monásticas. Trad. Hildegardis Pasch e Helena Nagem Assad. Petrópolis: Ed. Vozes, 1983, p. 76, 145.

* Com relação às origens da ordem beneditina, ver Claude J. NESMY. São Bento e a vida monástica. RJ: Agir, 1962. Para o comentário geral da Regra, Idelfonso HERWEGEN. Sentido e espirito da Regra de Sāo Bento. Trad. dos monges do Mosteiro de São Bento. RJ: "Lumen Christi", 1953, esp. pp. 115-146 e La Règle de Saint Benoit: commentaire historique et critique. Paris: Du Cerf, 1971.

*. S. P. BENEDICTI Regula cum commentaniis. In: J. P. Migne. Patrologiae Latinae. Tomus LXVI, col. 350 . 
O capítulo seguinte, chamado De Humilitate, é consagrado aos exercícios necessários para se combater um dos maiores obstáculos no caminho da purificação, o orgulho. Toda exaltação de si mesmo, toda valorização do próprio eu deveria ser tomado como manifestação do orgulho e da soberba, devendo ser aniquilados pela humildade sincera, pelo reconhecimento verdadeiro das limitações e potencialidades que cada um carregava consigo interiormente. Para ilustrar o ensinamento, Bento recorre à imagem alegórica da Escada de Jacó (que conduzia ao céu) para referir-se aos degraus que conduziriam à humildade. Nesta escalada, o riso apresenta-se como obstáculo a ser superado. $O$ décimo degrau da humildade consiste por isto mesmo na seriedade e gravidade do caráter. Para atingi-lo, o monge deveria evitar rir com facilidade: "Há de ser moderado e parco no rir, humilde e grave, não deve pronunciar senão palavras sensatas, nem produzir ruido com a própria voz".

Portanto, seja na perspectiva monacal, seja na perspectiva dos formuladores da doutrina, o riso costumava ser tomado como fator de indisciplina espiritual e motivo de culpa. Os moralistas da Alta Idade Média situavam-no entre os males a serem combatidos no comportamento dos leigos, criticando o excesso de alegria e a excessiva despreocupação destes com os deveres espirituais." Um dos maiores adversários da hilaridade, Cesário de Arles (470-542), denunciava em seus sermões o divertimento dos fiéis até mesmo durante os ofícios religiosos, condenando os homens que julgavam cumprir com a obrigação de ir a missa aos domingos ao ficar na porta dos templos jogando e rindo, e as mulheres tagarelas que conversavam alegremente até mesmo durante o sermão dominical. ${ }^{\text {3n }}$

Nos séculos seguintes, o combate espiritual contra o espírito de festividade continuava a ser levado a cabo pelos pensadores cristãos. Certos traços das restrições apresentadas ao espírito festivo e alegre podem ser identificados na obra de Isidoro de Sevilha, importante pensador e moralista ibérico do século VII. Em sua extraordinária Etimologiae, advertia sobre o perigo dos jogos circences e apontava a sua vinculação com os cultos idolátricos, bem como os riscos das palavras impróprias saídas da boca, uma das partes nobres do corpo que deveria ligar-se as coisas elevadas pertencentes à esfera divina. ${ }^{\mathfrak{}} \mathrm{E}$ Jonas de Orleãs, ativo participante da Renascença carolíngia do século IX, ao refletir sobre o modo de conduta dos leigos seus contemporâneos, não apenas mostrou-se desolado face as suas atitudes irreverentes, mas sintetizou com excepcional clareza a orientação que a Igreja procurava ver afirmada:

"Os primeiros cristãos comiam seu alimento com alegria e simplicidade no coração, louvando Deus, mas atualmente dificilmente come-se sem calúnias,

36 Idem, col. 435.

"3 Neste sentido, consultar Jean CHELINI. Histoire religieuse de l'Occident médiéval. Paris: Armand Colin, 1968, p. 150.

3. CÉSAIRE D'ARLES. Sermons au peuple. Éd. Marie-José Delage (Sources Chrétiennes, 175). Paris: Du Cerf/CNRS, 1971. Tome II, p. 472.

39 SAN ISDORO DE SEVILLA. Etymologiarum. Ed. e trad. Jose Oroz Reta y Manuel A. Marcos Casquero. Madrid: La Editorial Catolica, 1983. Tomo II, livro XVIII, pp. 404-428. Ver ainda Ruy de Oliveira ANDRADE FLLHO. "A respeito dos homens e dos seres prodigiosos: uma utopia do homem e de sua existência na obra de Santo Isidoro de Sevilha". Revista USP, 1995, p. 81. 
mentiras, insultos, saltos e bufonarias, sem histórias escandalosas ou divertimentos, ou tantas outras tolices que imperam no coração dos cristãos... O ventre aumentado pelas iguarias caras, irrigado pelos vinhos finos, não permite que se abra mais a boca para louvar Deus, mas apenas para dar grandes gargalhadas. Segundo a Escritura, Nosso Senhor Jesus Cristo chorou, e não riu. Neste ponto, como em todos os outros, ele deu o exemplo que, neste vale de lágrimas, não se deve rir pelas alegrias efêmeras que se desvanecem como fumaça, mas que é preciso chorar pela perda da herança de nossa Pátria Celeste, da qual nos encontramos por muito tempo exilados"."

O caminho em busca da perfeição, todavia, estava rodeado de perigos. As forças demolidoras da seriedade e austeridade rondavam as fortalezas da fé. Como privar-se completamente de si? Como morrer para o mundo? Muitos séculos depois de São Bento, tais dilemas incomodavam Aereld, abade inglês do mosteiro de Rievaux (1109-1166). Não satisfeito com a mera reprodução dos conselhos e preceitos da regra beneditina, ele elaborou um texto adaptado às necessidades e contingências de seu tempo, a Regula Sive Institutio inclusarum, ad Sororem, que, como o próprio título indica, destinava-se às reclusas dos mosteiros femininos.

A justificativa do abade inglês é no mínimo curiosa. Segundo ele, não bastava aprisionar 0 corpo. $O$ perigo persistiria enquanto a alma permanecesse exposta às tentações. De que adiantaria manter as portas do mosteiro trancadas, se as janelas permanecessem abertas? As janelas, na opinião de Aereld, eram o ponto fraco da fortaleza sagrada, por onde o "inimigo" costumava entrar sob a forma de maus pensamentos, suscitados pelos contos cômicos e/ou obscenos aos quais as reclusas, em vez de evitar, procuravam de todas as maneiras ouvir." Os redatores das regras monásticas do início da Idade Média, notando a relação entre o riso e o corpo, propuseram uma série de cuidados com a boca dos monges. Aereld, pela mesma razão, demonstra preocupação com os ouvidos, a porta de entrada tanto dos ensinamentos quanto dos pensamentos pecaminosos.

O desejo secreto do prazer, no juizo severo do abade, distanciava as monjas do ideal de perfeição almejado. Jamais, em sua opinião, podia-se encontrar uma que estivesse só, meditando e refletindo sobre as coisas sagradas. Pelo contrário, tagarelando em grupo, ou sentadas diante da janela a ouvir as estórias escandalosas e cômicas envolvendo a conduta duvidosa de padres e monges e a malícia de mulheres ou viúvas, as reclusas constantemente demonstravam satisfação na fisionomia alegre, em gargalhadas (risus cahinnosque) e até mesmo gritos. $\mathrm{O}$ veneno, bebido junto com estas "delícias", espalhava-se pelos seus corações e pelos membros. Mesmo aquelas que, com piedosas intenções, propunham-se a ensinar as crianças das redondezas, expunham-se ao perigo:

"Não permitas que meninos e meninas jovens aproximem-se de ti. Existem reclusas que se ocupam do ensinamento das crianças, e transformam sua célula em escola. A reclusa senta-se perto da janela, enquanto os jovens agrupam-se sob

w JONAS AURELIANENSIS EPISCOPUS. De Institutione Laicali Liber Primus. Patrologiae Latinae, tomus CVI, col. 164.

" J. J. JUSSERAND. "Les contes à rire et la vie des recluses du XII siècle". Romania, 24 annèe, 1895, pp. 122-128. 
o pórtico. Ela olha para os seus alunos e, de acordo com as atitudes infantis, ou os repreende ou põe-se a rir, ameaçando-os ou mimando-os, repreendendo-os ou abraçando-os. Se uma das crianças, após a punição, cai em prantos, é motivo para que a reclusa se aproxime para acariciá-la ou tomá-la nos braços, com os infinitos: minha pequena filha... minha querida". ${ }^{2}$

Qualquer contato exterior, qualquer demonstração de afeto, na concepção austera de Aereld, poderia colocar em risco a disciplina monacal. As demonstrações de alegria denunciadas pelo riso, e sobretudo pelo riso excessivo da gargalhada, constituiam faltas graves diante dos princípios da regra de vida espiritual. Era preciso vigiar as reclusas, impedindo-as de aproximar-se das velhas tagarelas que rondavam as janelas. Toda comunicação, todo contato exterior, todo espetáculo mundano deveria ser banido do espaço consagrado. Nem mesmo as servas poderiam escapar da vigilância. Até os confessores deveriam ser mantidos sob suspeita. No exercício da edificação da alma, as monjas deveriam falar pouco, humildemente e com moderação, nunca em voz alta e jamais com expressão risivel."

Contemporâneo de Aereld, São Bernardo destaca-se como expoente intelectual do monaquismo do século XII. Adversário do relaxamento moral, do luxo e do distanciamento das premissas originais da vida beneditina, elaborou em $1125 \mathrm{um}$ comentário ao capítulo VII da Regula, intitulado Liber de Gradibus Humilitatis et Superbiae. Retomando a imagem da Escada de Jacó, comentou os doze degraus da humildade, em linha ascendente, introduzindo, em ordem decrescente, os doze degraus da soberba. Situou o "riso fácil e vão" no terceiro degrau da soberba, e comparou o monge dado ao riso è à "tola alegria" a uma bexiga inflada de ar. Como ela, o orgulhoso e arrogante inflou seu coração com pensamentos jactanciosos. Como a disciplina do silêncio não permite a liberação do "ar da vaidade", ele sublima a gargalhada (cachinnos) comprimindo os lábios e apertando os dentes, produzindo sons sufocados e contidos."

A dissimulação do riso, no modo de ver do fundador da Ordem de Cister, é muito mais pernicioso que a explicitação do mesmo. A gargalhada contida revelaria o desejo íntimo que o monge deveria evitar com sinceridade. Esta gargalhada, expressão máxima do riso, mesmo que submetida pela regra do silêncio, continuava a alimentar o sentimento de arrogância; sentimento duplamente condenável, seja em virtude do descumprimento dos preceitos monásticos, seja em razão do ocultamento de comportamento pecaminoso. Para o abade de Claraval, a arrogância de determinados monges ligava-se à sensação de superioridade decorrente do saber acumulado. O saber genuíno, verdadeiro, todavia, deveria aproximá-lo de

12. AERELD DE REVAULX. La vie de recluse. Éd. Charles Dumont (Sources chrétiennes). Paris: Éditions Du Cerf, 1961, p. 53.

13 Idem, p. 55.

" SAN BERNARDO. Liber de gradibus humilitatis et superbiae. In: Obras completas (Biblioteca de Autores Cristianos). Madrid: La Editorial Catolica, 1983. Tomo I, p. 228. Sobre as idéias de São Bernardo a respeito da arte, cultura e filosofia de seu tempo, ver Georges DUBY. São Bernardo e a arte cisterciense. SP: Martins Fontes, 1991. 
Deus, e não de si mesmo. $\mathrm{Na}$ condenação ao riso do monge, estava incluída a condenação da soberba moral e uma censưra contra a curiosidade intelectual. "t"

O século de São Bernardo, entretanto, representou importante ponto de inflexão no pensamento cristão ocidental, inaugurando um novo modo de pensar o mundo e o sagrado, cuja formulação clara tornar-se-ia dominante nas universidades do século XIII. Esta mudança de orientação no modo de conceber o conhecimento pode ser observada na revalorização dos aspectos profanos ou naturais da vida humana, assim como no modo de explicar a essência divina a partir de princípios elaborados com base na especulação filosófica. Neste sentido, costuma-se falar de um Renascimento no século XII, integrado em amplo processo de renovação cultural, calcado em profundas transformações sociais e econômicas vividas na Europa feudal. ${ }^{\text {s. }}$

Este impulso de renovação cultural afetou as formas tradicionais do pensamento cristão. Nas escolas, e nas universidades nascentes, a lógica e a dialética ocupariam aos poucos o seu lugar nas premissas teológicas. A tradição intelectual continuava a fundamentar-se num platonismo mitigado, mas retomou contato com o pensamento aristotélico através dos tradutores e/ou intérpretes árabes." O homem passou a se inserir na criação divina. Concebido como um microcosmo, ele veio a ser integrado e associado ao macrocosmo, o mundo criado e ordenado por Deus. Paulatinamente, deixou de existir oposição radical entre o sensivel e o inteligível. O mundo concreto passou a ser apropriado pelas idéias. A "natureza" transformou-se em objeto de reflexão. Como afirma M. D. Chenu, a preocupação com os fenômenos extraordinários, as mirabilia, cedeu passo diante de uma conduta destinada a tentar compreender as seqüências regulares e determinadas, especialmente nos fenômenos da vida. A natureza começou ao mesmo tempo a ser dessacralizada, sendo colocada a serviço do homem."

Podemos falar, pois, de uma revalorização das categorias profanas da existência, de um humanismo que penetrou nos modos tradicionais de pensar, alterando as formas de concepção do mundo. Tal alteração pode ser verificada nas manifes-

4. Não há como deixar de notar, neste como em outros pontos, certa similaridade da conduta de São Bernardo com a do personagem ficticio Jorge de Burgos, criado por Umberto ECO em O Nome da Rosa. Trad. Aurora F. Bernardini e Homero F. de Andrade. RJ: Nova Fronteira, 1983. Numa passagem célebre do romance, o velho monge cego pergunta, em meio a um sermão sobre a vinda do Anticristo: "Qual é o pecado de orgulho que pode tentar um monge estudioso? $O$ de entender o próprio trabalho não como custódia mas como busca de alguma notícia que năo tenha ainda sido dada aos humanos", p. 453, e, no debate com Guilherme de Baskerville, pronuncia terrivel imprecação contra os amantes da derrisão: "Se um dia - e não mais como exceção plebéia, mas como ascese do douto, consignada ao testemunho indestrutivel da escritura - se tornasse aceitável, e aparecesse nobre, e liberal, e não mais mecânica, a arte da irrisão, se alguém um dia pudesse dizer (e ser escutado): eu rio-me da Encarnação... Então não teriamos armas para deter a blasfêmia, porque ela conclamaria as forças obscuras da matéria corporal, as que se afirmam no peido e no arroto, e o arroto e o peido arrogariam a si o direito que é só do espirito, de soprar onde quer!", $p$. 535.

w A este respeito, ver Christopher BROOKE. O Renascimento do século XII. Trad. antonio G. Mattoso. Lisboa: Ed. Verbo, 1972 e Jacques LE GOFF. Os Intelectuais na Idade Média. S/local: Ed. Estudios Cor, 1973.

" Cf. Ruy Afonso C. NUNES. Gênese, significado e ensino da filosofia no século XII. SP: EDUSP/GRIJALBO, 1974, esp. pp. 157-162.

M. D. CHENU. La théologie au douzième siècle. Paris: Librairie J. Vrin, 1957, pp. 34-42. 
tações de sensibilidade religiosa, que se voltaram com maior insistência para o culto de um Cristo sofredor, em toda a sua humanidade. Face a imagem do Cristo Juiz, o Pantocrator que julga impávido no Dia da Ira, popularizou-se a imagem do Cristo crucificado ou do Cristo Menino. A imagem onipotente do Deus-Pai, revestida de traços patriarcais de autoridade, marcou o contraste com a popularidade do culto à Virgem Maria - a mãe de Deus capaz de interceder junto ao filho para salvar os homens."

Estas modificações profundas verificadas na cultura clerical concorreram para a redefinição do lugar dos gestos e, pela mesma razão, do lugar do riso nos sistemas de valor aceitos pela religião oficial. Jean-Claude Schmitt notou com bastante perspicácia a referida mudança de orientação na postura dos clérigos. Para ele, a cultura cristã atribuiu durante muito tempo conotações negativas à noção de mobilidade, associando-a ao transitónio, ao instável, ao terrestre. A mobilidade caracterizava o homem camal, a tentação do pecado, a agitação do vício, opondo-se ao movimento celeste, regular e imutável. Apenas nos séculos XII e XIII certas imagens passaram a ser figuradas de modo a denotar movimento, recebendo certa valorização por parte dos escritores.

A partir de então, os moralistas e teólogos emitiram juizos mais favoráveis em relação à gesticulatio, a gesticulação. A maior condescendência para com a liberdade de expressão dos movimentos não decorreria da já mencionada valorização do homem face às potencialidades do sagrado? Os moralistas do tempo alargaram o debate sobre a propriedade e a admissibilidade do riso fora da esfera clerical, estabelecendo uma distinção fundamental entre o bom e o mau riso, isto é, entre o riso de alegria e felicidade, cum iucunditate, e o riso vão, cum iocositate.

Considerando o fato de que os séculos XII-XIII assinalaram a emergência de formas culturais profanas, gestadas nas cortes principescas feudais, as discussões levadas à cabo pelos teólogos e moralistas ganharam maior dimensão. Não se tratava apenas de vilipendiar ou enaltecer os comportamentos subjacentes ao ato de rir, mas demarcar fronteiras bem definidas entre gestos aceitáveis ou condenáveis no mundo dos leigos. Compreende-se, pois, a insistência na condenação do riso desmedido, de sarcasmo, zombaria ou deboche. Visava-se manter sob controle atitudes que pudessem colocar em risco o equilibrio nas boas maneiras, isto é, aquelas condizentes com o espirito cristão.

Convém assinalar, neste sentido, uma alteração semântica sutil concernente ao riso. Foi no texto De Nugis Curialium, composto no final do século XII (entre 1181 e 1193) por Gautier Map e destinado à corte plantageneta, que apareceu pela primeira vez a expressão subridens (sorriso), que nos remete de imediato para as formas comedidas ligadas aos gestos risiveis. A obra em questão, aliás, sintetizava elementos da tradição céltica e da cristã, perpassadas por conteúdo de cunho educativo. Pretendia divertir os integrantes da corte, sem deixar de fornecer-lhes preceitos morais edificantes."

* Georges DUBY. O tempo das catedrais: a arte e a sociedade (980-1480).Trad. Jose Saramago. Lisboa: Ed. Estampa, 1979, pp. 102 e segs.

* GAUTIER MAP. De Nugis Curialium. Ed. M. R. JAMES. Oxford: Clarendon Press, 1914, p. 226. 
O “riso cortês" apresentava-se aos representantes da cultura clerical imbuido de conotações demoníacas. Os hábitos da vida cortesã, via de regra, eram associadas com o inferno. O tratado teológico-moral de Giraldus Cambrensis, Speculum Duorum, redigido na passagem do século XII para o XIII extraía do mundo profano exemplos de virtudes e vícios, quer dizer, de comportamentos considerados positivos e daqueles tidos como negativos. Entre os últimos, inclui o deboche, a zombaria e o escámio, vinculando-os ao caráter nefasto do riso.

O moralista relaciona o riso sarcástico e de zombaria com o desrespeito para com Deus e para com a família. A aproximação simbólica entre a "família celeste" e a "familia terrena" reforçava certamente o peso das atribuições conferidas ao gesto. O desrespeito expresso no deboche afetaria toda a familia do emissor e da vitima, quebrando com a hierarquia necessária na relação entre pais e filhos. Giraldus cita frases de Demócrito e Sêneca contrárias ao gesto risivel, somando-as com diversas passagens dos livros sapienciais do Antigo Testamento, extraidas em especial dos textos atribuidos a Salomão.

No ensejo de fortalecer seus argumentos, retira do texto vetero-testamentário a figura típica do ridente pecaminoso: Cam. Fazendo referência à conhecida passagem do Gênesis, em que o terceiro filho de Noé riu ao ver a nudez paterna," o escritor situa os debochadores na linha dos descendentes da raça maldita dos Camitas. Indo além, realiza, por via de aproximação semântica, os termos Cam, Caim (assassino do próprio irmão Abel) e os judeus - que riram diante do martírio de Cristo." Deste modo, enfileira os ridentes excessivos na "linhagem" dos amaldiçoados, cuja punição era a de permanecerem na condição de escravos. Assim, como na concepção clerical então em voga Deus teria criado três categorias distintas no mundo - Oratores, Bellatores, Laboratores - aqueles enquadrados na última (os servos) seriam os remanescentes de Cam, e o riso sarcástico constituiria uma das marcas de seu estigma. ${ }^{: "}$

A restrição frente ao riso desmedido baseava-se, segundo pensamos, em três idéias complementares. Primeiramente, seu aspecto corrosivo poderia colocar em perigo o equilíbrio da familia/linhagem. Em segundo lugar, ao provocar o desequilíbrio numa ordem instituida por Deus, afrontaria da mesma forma a ordem supraterrena. Em terceiro lugar, devendo ser banido das esferas anteriores, seria por isto mesmo próprio das esferas inferiores da sociedade, sendo a inferioridade a decorrência de uma punição divina anterior.

Timidamente, porém, algumas vozes do século XII tenderam a se levantar, questionando com sutileza a inadmissibilidade da derrisão. Hugo de São Vitor, autor de De Institutione Novitiorum, e Pedro o Venerável, argumentaram sobre a

\$1 A cena aparece retratada nos testemunhos iconográficos do período, como nos informa o bem documentado estudo de Hilário FRANCO JR. "A castração de Noé: iconografia, folclore e feudalismo". In: A Eva barbada: ensaios de mitologia medieval. SP: EDUSP, 1996, pp. 71-87.

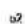
GIRALDUS CAMBRENSIS. Speculum Duorum. Ed. Yves LEFEVVRE/B. C. HUYGENS. Cardiff: University of Wales Press, 1974, p. 32.

43. Seguimos nesta passagem a interpretaçâo de Jacques LE GOFF, apresentada no seminário "Le rire au Moyen Age", realizado na École de Hautes Études en Sciences Sociales durante o mês de novembro de 1991. agradecemos a prof" Silvia Regina Ferraz Petersen pela gentileza no fornecimento dos textos ali discutidos, acompanhados de suas anotações pessoais. 
liberdade do bom cristão rir em determinadas circunstâncias, cabendo ao primeiro a afirmação segundo a qual "Algumas vezes as brincadeiras costumam agradar mais, misturadas às coisas sérias". E João de Salisbury, um dos grandes nomes do renascimento intelectual, discute em seu tratado sobre a ética, o Policraticus, a relação do riso com a essência humana. Porém, permanecia a velha questão: tendo Cristo sido homem, teria ele rido alguma vez?"

É bem possivel que a relação do riso com o caráter humano tenha derivado da influência do pensamento aristotélico sobre os letrados da Idade Média central. A definição de Aristóteles, segundo a qual "o riso é próprio do homem", esteve inserida nos debates dos mestres das universidades do século XIII, aparecendo nos textos dos escolásticos. Mesmo certos autores revestidos de autoridade na tradição filosófica cristã, como Marciano Capella, que em seu De Nuptiis Philologiae et Mercunii - redigido no século $\mathrm{V}$, mas retomado e revalorizado apenas por ocasião do Renascimento do século XII - afirmava: "o homem é um animal risível", ou Boécio e até mesmo Alcuíno, serão tomados como referencial para os argumentos dos defensores da risibilidade dentro dos quadros do pensamento cristão."

A questão da admissibilidade do riso ganhou uma dimensão dificil de ser compreendida por nós, modernos. Reconhecer o riso como uma propriedade inerente ao ser humano implicava em reconhecer que Cristo, como homem que tinha sido, ria como os demais. O debate sobre se Cristo riu, "bizantino" aos nossos olhos, assumiu extrema gravidade, pois colocava em dúvida não apenas os argumentos de respeitáveis representantes da patrística - como São João Crisóstomo -, mas remetia para a valorização de um lado de Cristo mantido até então em segundo plano: o seu lado humano. ${ }^{*}$

A dificuldade encontrada pelos eruditos ao tratar desta matéria aparece com relativa transparência no raciocínio desenvolvido pelo professor de teologia da Universidade de Paris chamado Pedro Cantor. No tratado Verbum Abbreviatum, escrito em 1178, fica patente os caminhos tortuosos trilhados por aqueles que procuravam conciliar a tradição oficial cristã com a especulação filosófica fundada em princípios da lógica e da razão. Colocando a questão de Cristo ter ou não rido, argumenta:

"Parece que, havendo uma causa íntima, existia nele uma alegria boa, que pôde externar no ato do riso, sobretudo por ter assumido todos os nossos defeitos, exceto a culpa; tanto mais que o risivel ou a risibilidade é uma caracteristica do homem, dada pela natureza. Como, então, não poderia servir-se dele? Terá, talvez, podido, mas não se lê que dele se tenha servido"."

Observemos os exercícios de retórica e os malabarismos nos argumentos do professor de teologia. Para ele, Cristo poderia ter rido (com esta proposição, apa-

* Emst R. CURTIUS. "Gracejo e seriedade na literatura medieval". In: Literatura européia e Idade Média latina. RJ: MEC/INL, 1957, p. 441.

s J. S. P. TATLOCK. "Medieval laughter". Speculum, XXI, 1946, pp. 289-294; Helen ADOLF. "On mediaeval laughter". Speculum, XXII-2, 1947, pp. 251-253.

"Jacques LE GOFF. “Jésus a-t-il ri?". L'Histoire, 158, 1992, p. 73.

i) PETRUS CANTORIS. Verbum abbreviatum. In: J. P. Migne. Patrologiae Latinae. Tomus CCV, col. 305. 
rentemente entra em confronto com a tradição secular contrária ao gesto), sem que isto possa significar que realmente tenha experimentado (o que preserva a tradição). A faculdade de rir aproxima Cristo do gênero humano, porém dado o riso ter estado entre os gestos condenáveis na literatura patristica, admitir esta possibilidade eqüivalia a entrar em confronto com as autoridades teológicas anteriores que tinham proferido parecer contrário em relação ao mesmo. A solução do escolástico parisiense torna-se, pois, conciliatória: Cristo era dotado da faculdade de rir (um defeito); poderia servir-se desta faculdade (o que o igualaria a qualquer ser humano), sem que o tenha feito. Os termos da conciliação, portanto, tinham limites claros, pois o riso, mesmo tendo sido resgatado e transformado em objeto de reflexão, permanecia na condição de sintoma de pecado: se a faculdade de rir era intrínsica à condição humana, então era sinônimo de mácula e degradação.

Tratava-se, como vemos, de não estabelecer confronto aberto com os opositores do riso, cujas formulações provinham da exegese bíblica. Segundo os argumentos exegéticos, o texto das Escrituras deveria ser seguido de forma literal. Assim, como nos testamentos não há menção ao riso de Cristo, então Cristo jamais riu. $\mathrm{O}$ dado textual era tomado como verdade absoluta. Em meados do século XIII, o místico São Boaventura, no De Perfectione Vitae ad Sorores, não continuava a argumentar em favor do silêncio das monjas, afirmando que a Virgem Maria somente conversou com quatro pessoas, e que não falou mais do que sete vezes: duas com o anjo da anunciação, duas com seu Filho, duas com Isabel e uma vez com os servidores durante das Bodas de Caná? Evidentemente, o Doutor Seráfico referia-se às indicações bíblicas sobre as conversas de Maria, mas sugere a partir das evidências textuais que de fato a mesma só tivesse falado sete vezes durante toda a vida!

Com as reflexões e especulações desenvolvidas pela escolástica na segunda metade do século XIII, o riso acabou sendo incorporado, em graus diferenciados, ao pensamento cristão. Encontramo-lo mencionado na obra filosófica oriunda dos meios universitários, especialmente nos escritos dos teólogos oriundos das ordens mendicantes. Ao lado dos continuadores da tradição iniciada por São Francisco de Assis - que se autodenomidava "jogral de Deus" - surgiram outros defensores da idéia de que o riso não era essencialmente mau. Um dos maiores pensadores do cristianismo medieval, o dominicano São Tomás de Aquino, em sua magistral Summa Theologiae, defendeu a licitude do lúdico e do jogo, insistindo no argumento segundo o qual o "prazer alegre" e "humorístico" era necessário ao ser humano. ${ }^{\text {. }}$

Leitor atento de Aristóteles, e indubitavelmente seu maior intérprete no Ocidente cristão, São Tomás reconheceu na derrisão uma propriedade da natureza humana. Não se limitou, todavia, a esta constatação. Atribuiu ao gesto significados positivos. Para ele, a hilaridade era faculdade essencialmente boa do homem, deixando de ser considerada obstáculo para o cristão. O riso comedido, nesta

sh SAN BUENAVENTURA. De perfectione vitae ad sorores. In: Obras (Biblioteca de Autores Cristianos). Madrid: La Editorial Catolica, 1947. Tomo IX, p. 438.

ts John SAWARD. Dieu à la folie: histoire des saints fous pour le Christ. Trad. Marie Tadié. Paris: Seuil, 1983, p. 130. 
percepção, deixou de ser julgado ato ofensivo a Deus. No conjunto de textos do fundador do tomismo, subsiste a idéia da existência de um riso nefasto, provocado por palavras indecorosas, obscenas ou imbecis, e um riso de dor e agonia, desaprovados. A tristeza, sentimento adverso à alegria e hilaridade, seria tão temerária quanto a expressão desenfreada do "riso louco". A acídia confunde-se com o pecado porque conduz ao desgosto diante das potencialidades do espirito, à astenia e ao desespero d'alma. Porém, o riso pode também ser associado ao estado de alma plenamente positivo: a felicidade. Para São Tomás, a letitia, o deleite espiritual, era um bem reservado aos eleitos à salvação eterna.

Neste ponto, vale assinalar a preocupação do Aquinate com as formulações aristotélicas concernentes aos princípios éticos relacionados ao estado da felicidade humana, desenvolvidas pelo pensador grego no texto da Ética a Nicomaco e retomadas pelo intérprete no comentário para a mesma, o In decem libros ethicorum Aristotelis ad Nicomachum expositio, bem como em certas passagens da Summa Theologiae. Ambos, neste ponto, concordam quanto ao fato de que a felicidade constitui o fim último da existência, o bem supremo entre todos os bens humanos por ser a potência melhor que há no homem, definivel pela razão. ${ }^{\infty}$

A felicidade perfeita, por isto mesmo, estaria ligada as qualidades do intelecto e ao ideal da contemplação. No pensamento tomista, ela não residiria no prazer, nem na vida virtuosa, mas na contemplação da perfeição em si, isto é, Deus. São Tomás concordava, desse modo, com Santo Agostinho, para quem Deus não possui a felicidade, é a felicidade plena e absoluta. Neste raciocinio, o homem atingiria a felicidade ao aproximar-se de Deus. Por isto, afirmava que a contemplação de Deus era felicidade no homem, ao unir-se a Ele pelo ato de sua virtude mais elevada - o intelecto - no exercício espiritual da contemplação. ${ }^{.1}$

Por este raciocínio, o riso enquanto expressão do prazer obtido na existência terrena não poderia ser completamente aceito e legitimado. De fato, a valorização notada incide no riso pleno de felicidade, que só poderia ser alcançado no estado de contemplação absoluta da obra divina, isto é, no Paraiso. A certeza da salvação provocaria imensa alegria (gaudium immensum), e o riso paradisiaco suplantaria todos os gozos terrestres. A felicidade, fim último do homem, realizar-se-ía na beatitude do riso celeste. Como afirma Michel-Marie Dufeil, na formulação tomista o riso é integrado numa escala, indicando distintos estados de espírito, sendo distinguidos o riso doloroso, o riso alegre e o riso de glória. Portanto, mesmo na especulação elaborada do escolástico, a verdadeira pátria do riso estava no Céu."

Acreditamos que estes dados sejam suficientes para que possamos pelo menos vislumbrar as oscilações de significado do riso e as ambivalências da cultura clerical face a dimensão cultural do mesmo dentro dos sistemas de valores difundidos pelo cristianismo. Longe de ser interpretado de forma unívoca, seu caráter e

* Maurício CAMELLO. "A felicidade como bem supremo: Santo Tomás lê Aristóteles". Veritas: Revista Trimestral de Filosofia e Ciências Humanas da PUCRS, 159, 1995, pp. 509-516.

a1 Luis A. DE BONI. "Tomás de Aquino e Boécio de Dácia: leitores dos clássicos a respeito da felicidade". Veritas, 159, 1995, esp. pp. 524-528.

(2) Michel-Marie DUFEIl "Risus in theologia Sancti Thome". In: Thérèse BOUCHE/Hélène CHARPENTIER (Orgs). Le rire au Moyen Age dans la littérature et dans les arts. Bordeaux: Presses Universitaires de Bordeaux/CNRS, 1990, pp. 154-158. 
seu lugar no código de ética e nos preceitos morais pensados e orientados pela elite intelectual cristã na Idade Média jamaịs foi uniforme e imutável. Pelo contrário, tais oscilações revelam, em nosso entender, os impasses e as alterações no modo pelo qual os representantes da Igreja conceberam o mundo e os fenômenos humanos.

Deste modo, podemos, com Jacques le Goff, distinguir três grandes tendências que nortearam a apreciação dos representantes da cultura clerical em relação a risibilidade: na primeira, vigente na Alta Idade Média, marcada sobretudo pelos pensadores gregos da Patrística e pelo paradigma monástico, o gesto foi tendencialmente condenado e revestido de conotação satânica; na segunda, emergente na Idade Média Central, orientada pelas premissas "humanistas" trazidas à tona pelo Renascimento do século XII e as universidades, assiste-se a uma liberação controlada da derrisão, sendo-lhe reconhecidas potencialidades antes peremptoriamente negadas; e na terceira, cuja manifestação apareceria nos séculos finais da Idade Média, o riso irromperia em todas as manifestações culturais de cunho profano."

Jacques LE GOFF. Art. cit., p. 74. 